\title{
Male and Female Motivations for Participating in a Mass Cycling Race for Amateurs. The Skoda Bike Challenge Case Study
}

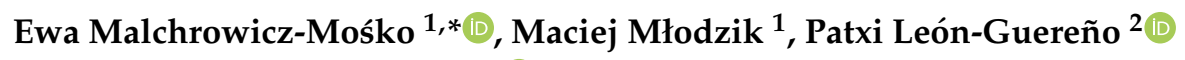 \\ and Katarzyna Adamczewska ${ }^{3}$ (D) \\ 1 Faculty of Sport Sciences, Department of Sports Tourism, Poznan University of Physical Education, \\ Krolowej Jadwigi 27/39,61-871 Poznan, Poland; maciej_mlodzik@wp.pl \\ 2 Faculty of Psychology and Education, University of Deusto, Camino Mundaiz 50, \\ 20012 San Sebastian, Basque Country, Spain; patxi.leon@deusto.es \\ 3 Faculty of Health Sciences, Poznan University of Physical Education, Krolowej Jadwigi 27/39, \\ 61-871 Poznan, Poland; adamczewska@awf.poznan.pl \\ * Correspondence: malchrowicz@awf.poznan.pl; Tel.: +48-696-057-313
}

Received: 4 October 2019; Accepted: 21 November 2019; Published: 24 November 2019

\begin{abstract}
The purpose of our research was twofold: to investigate the motivations for participating in a mass cycling event for amateurs and the motivational differences between men and women in cycling. This empirical study involving 385 cyclists was conducted during the fifth edition of the Skoda Bike Challenge held in Poznań in 2018. The event forms part of the UCI Gran Fondo World Series of events organized around the world, which are sanctioned by the Union Cycliste Internationale (UCI). A diagnostic survey method with a standardized interviewing technique was used to interview cyclists. The interview questionnaire was divided according to the MPAM-R scale (Motives for Physical Activity Measure-Revised). This scale assesses people's motives for participating in physical activities. The following motivations were examined: appearance, fitness, social, competence/challenge, and enjoyment. Descriptive statistics were used. A chi-square test was used to determine characteristics between responses. Cramer's $\varphi$ for statistically significant scores was indicated. The research results show some differences between male and female motives for competitive amateur cycling. Statistically significant differences were found between the following motives: interest/enjoyment, competence/challenge, and fitness. This is important information from the point of view of promoting cycling and for organizers of cycling events in regions wishing to promote sports tourism as a form of sustainable development. An understanding of mass cycling motivations is needed, as such knowledge can be used to encourage cycling, which has a potentially positive effect on future cyclists' physical and mental health. Learning about cycling motivations also allows us to determine which physical and mental health functions are fulfilled by mass sporting events and how to prepare for them. The motives for participating in mass cycling events for amateurs in Europe constitute an interesting field of research. The first part of the paper presents the literature review related to cycling in the context of motivations, sporting events, tourism, event management, and sustainable development, and the second part presents the results of our empirical study.
\end{abstract}

Keywords: cycling event; sports tourism; sustainable development; cycling motivation; bicycle tourism; health benefits of cycling

\section{Introduction}

Contemporary sport is increasingly incorporating ideals of sustainable development as one of its elements, which, it is assumed, relate to improving quality of life. Sports for all, for example, running 
or cycling, can increase personal life satisfaction and subjective well-being, bringing numerous benefits to individuals and society, such as [1-10]: keeping physically fit, dispelling fatigue, relieving stress, improving mood, and asserting self-affirmation. In terms of social benefits, recreational sport can build interpersonal relationships and social networking. Cycling has also health benefits-it has a positive impact on cardiovascular health and may decrease the chance of dying from a heart-related condition. Mass sporting events are now extremely popular among many sports enthusiasts. Currently, the most popular mass sporting events include, among others, marathons, cycling events, and triathlons. This dynamic increase in mass sporting events comes with questions concerning the motivations for participating in them. Understanding the motivation behind undertaking the physical activity of cycling among men and women is important for sustainable development in three ways. Firstly, getting involved in cycling as a form of sport and recreational activity can encourage cycling as an everyday, eco-friendly means of public transport. Secondly, sport encourages harmonious psychophysical development and improves quality of life, which is one of the goals relating to the idea of sustainable development. Understanding the motivations of both sexes has practical implications because it also encourages women to take up sport and allows them to be reached through social campaigns. Thirdly, knowing the motivations for participating in sporting events enables public finances to be managed rationally, for example, by conducting well thought-out marketing strategies on the part of event organizers and tourist regions where they take place.

Many researchers are interested in the issue of motivation in sport. One of the most important pieces of research is self-determination theory (SDT). Its assumptions are based on the psychological needs of autonomy, competence, and relatedness. SDT provides an explanation in order to understand the factors encouraging motivation and healthy functioning. Deci and Ryan point to the importance of intrinsic motivation, which is the most self-determined motivation for extrinsic motivation and amotivation [11]. Hulleman et al. investigated the effect of extrinsic motivation on the results of cyclists' times. No such impact was noted [12]. Frederick-Recascino and Schuster-Smith assessed the relationships between physical activity, competitive attitudes, participation motives, and adherence degrees among fitness trainers and racing cyclists. They claimed that among cyclists, competitiveness was correlated with interest motivation, enjoyment, and days of training (per week). The Motivation for Physical Activity Measure (MPAM-R) was used [13]. Streitcher and Saayman looked at cycling events in South Africa and identified main travel factors: social aspects, event prestige, personal motivation, relaxation, escape, and event features. The motivations behind cycling were generally intrinsic [14]. McCormick et al. (2018) researched how athletes participating in running, triathlons, and road cycling currently get guidance on psychological aspects of sporting events [15].

\subsection{Socio-Psychological Benefits of Mass Sporting Events for Men and Women}

Mass sporting events are an increasingly popular field of investigation among researchers. In terms of gender, there is a lot of research on gender-based motivational differences and health benefits in mass running [16]. Ogles and Masters stated that the most important motives for running among women are social needs and physical fitness, whilst for men, it is more about competing and being successful [17]. Summers et al. reported that female runners, more often than men, highlight the opportunity to meet new people and old friends [18]. According to Malchrowicz-Mośko and Poczta, mass running in half-marathons offers many social and psychological benefits, and the need to be physically fit is not a dominant factor. The significant differences between male and female motivations in this study appeared in relation to factors of desire to get away from everyday life and the prevailing fashion for mass runs, which often turned out to be more important for women than for men. The desire to win was not equally important for both genders. The need to experience strong sensations and emotions during the race was equally important to both genders, as was the need to feel a part of something and bond with other runners, and the desire to put themselves to the test [19]. Recent research on ultramarathon runners indicates that rivalry is also an important aspect among women [20]. Smith investigated elite female triathletes' motivation [21], and Fernandez-Lopez et al. [22] examined the 
relationship between gender and motivation among triathletes. There are few studies on motivational gender differences in amateur cycling.

\subsection{Cycling as a Sustainable Means of Public Transport}

In recent years, cycling has grown in public popularity. Transport is one factor contributing to global warming. Changing the way we travel is an effective way of reducing greenhouse gas emissions. Cycling is particularly recommended as an alternative means of transport [23]. This type of mobility can also reduce traffic congestion and noise [24]. Encouraging people to cycle is the goal of many cities in terms of quality of life, health, or environmental protection. Understanding cyclists' needs and behavior is a key issue when persuading cities to put cycling infrastructures in place, and in urban transport management. Researchers distinguished categories of cycling enthusiasts: recreational-, fair-weather-, path-using-, and dedicated-cyclists [25]. Aging can result in physical limitations, but many people still wish to stay active. Older people need alternatives that can assist their physical activity. One such option is electric bicycles. Johnson and Rose claim that electric bicycles increase regular physical activity [26]. Oja et al. demonstrated that health-beneficial cycling can be effectively promoted during work trips with relatively low financial outlays in the workplace [27]. Female cyclists are also proven less likely to ride a bicycle to work than male cyclists but are likely to use this means of transportation on other types of trips [28].

\subsection{The Meaning of Mass Sporting Events for Sports Tourism in the Light of Sustainable Development}

Previous studies mainly assessed the type of mobility as a means to an end, and not as an important element of a tourist package, especially in tourist destinations. Lumsdon appraised the Sustainable Transport Network Plan, the National Cycle Network in the UK, as a positive template for combining recreation, tourism, and transport. Lumsdon presented an idea of sustainable transport development in the city and pointed out many aspects that should be taken into account when introducing similar tourist transport models [29]. Han et al., rather, studied the decision-making phases of tourists with regard to cycling as a type of sustainable transport [30]. Recently, scientific publications have focused on mass, popular street runs in the context of the meaning of sporting events and active tourism, or the context of the motivation for running or health implications for runners $[4,19,31-36]$. Even the combination of running and sightseeing in the form of sight-running is increasingly prevalent [37]. The phenomenon of sight cycling is also observed. Some cities are projecting their tourist image on cycling, such as the rolling hills of Sheffield or Antwerp [38]. Bicycle tourism is becoming increasingly popular as a recreational and sporting activity, and is increasingly attracting researchers' attention in terms of its impact on physical and mental health [39]. Bicycle tourism has a promising future as a niche tourism industry that has potentially positive economic, health, social, and environmental benefits for cyclists and hosts [40], so research on participants in this activity and their motivations are important [41,42]. Ritchie et al. studied the behavior and needs of cycling tourists in Australia, who were divided into five groups according to level of involvement. Many significant differences were found in the motivations and behavior of cycling tourists based on socio-demographic characteristics [41]. Buning and Gibson analyzed the impact of transport conditions on the destination, event, and characteristics of tourists who travel to participate in cycling events [43]. Despite the increasing focus on cycling infrastructure and its management, many researchers ignore aspects such as cyclists' needs and degree of satisfaction with travel arrangements [44]. The purpose of the study by Brown et al. was to identify the ecological, cultural, and subcultural factors of Australian participation in organized cycling (using the CMI-Cyclist Motivation Instrument), providing sports organizations with greater insight into dedicated recreational cycling enthusiast preferences [45]. According to Brown et al., dedicated recreational cyclists do not prefer structured forms of sport. They prefer to join in with other like-minded cyclists who get together and compete on public roads. They are not partial to competing in official competitions organized by federations and sports clubs. Brown et al. have developed their own research tool based on Sallis et al.'s socio-ecological theory [8]. 
Understanding the gender characteristics and motives for participating in contemporary sporting events is important for event organizers, host cities, and tourist destinations seeking to make a bid to organize mass events. Many cities have developed strategies to organize sporting events and allocated resources to attract prestigious competitions. The effective management of contemporary sporting events and sporting event tourism cannot take place without first learning about athletes' motives, who are currently an important segment of the tourist industry, and who can affect a region's economic recovery [46]. Many tourist regions see such events as an important element of sustainable sports tourism but, unfortunately, the experience of some cities shows that hosting sporting events may also lead to negative effects, for example, overspending on organization. The high costs of organizing an event and lack of revenue from sports tourists may result in the need to increase fees or taxes in a given city [47-50].

Bicycle tourism is one of the national tourist products in Poland, which abounds in natural spaces and good cycling infrastructure in cities. Bicycle tourism in Poland enables the social and economic activation of rural areas, which is part of the EU's Europe 2020 growth strategy implementation priorities. Poland is included in 10 European countries where expenditure on bicycle tourism is highest (approximately $€ 2$ billion). Experts also pointed to a favorable proximity to the German market, which yields the largest revenue from this type of tourist activity. There are $982 \mathrm{~km}$ of international cycle routes in Poland nationwide-together with $897 \mathrm{~km}$ of other types of cycle routes, Poland has 12,700 km of tourist cycle routes. Most cyclists using the routes are young, physically fit, aged 18-30, families with children, and the elderly. The most important Polish tourist products related to cycling are tourist cycling routes with extensive accompanying infrastructure, accommodation facilities adapted to the needs of bicycle tourism, and events-cycling festivals and regular sporting events, bike rallies and trips, and local tourist products being developed on the basis of emerging tourist routes. The most popular bicycle tourism products in Poland are a network of 12 cycle routes for mountain bikers in Szklarska Poręba, a network of cycle routes in Greater Poland, the city bicycle network in Gdańsk, Greenways routes (for example the Amber Route: Budapest-Cracow, Green Bike: Greenway Eastern Carpathians, Green Trail Cracow-Moravia-Vienna), and the European Eurovelo network of 12 tourist routes-a European Cyclists' Federation project. The EV2, EV4, EV9, EV10, and EV11 routes run through Poland [51,52].

\section{Mass Sport Participation in Polish Society-Research Background}

Interest in sport in Polish society has increased significantly over the past several years. After the accession of Poland to the European Union, it was one of the countries with a society with the lowest physical activity (PA) per citizen. It is currently in mid-position, which is quite a significant increase [53,54]. Active leisure time spent is a distinctive component of the Polish middle class now $[55,56]$. Polish society's favorite sport is cycling (53\% of physically active people), running $(33 \%)$, and swimming (29\%) [54]. The percentage of Poles aged 15-69 fulfilling the World Health Organization recommendations on regular physical activity stands at $18.5 \%$. Participation in physical activity is greater among men than women $(21.5 \%$ as opposed to $16 \%)$. The percentage of active population recommended by the WHO is higher among the young, the wealthy, and university graduates. In addition, $13 \%$ of respondents in Poland reported performing intensive physical activity at least four times a week, yielding similar results to the average of other European Union countries-16\%. Twenty-seven percent of Polish society performs physical activity one to three times a week (EU average- $29 \%$ ). Among the EU residents who stated that they perform physical activity at least once a week, Finland (63\%), Sweden (61\%), Denmark (60\%), and Germany (58\%) are the highest ranking [57]. Seventy percent of Poles report that their immediate vicinity offers a wide range of opportunities to be physically active. This confirms the improved availability of sports and recreational infrastructures. Thirty-eight percent of Poles believe that local authorities are doing enough to ensure that citizens are able to take physical exercise [58]. According to data from the Central Statistical Office in Poland, $20.3 \%$ of Poles reported participating in unorganized sports and recreational activities in their free 
time at least once a week. However, $25.6 \%$ reported sporadically participating in physical recreation organized by them [59]. In terms of the percentage of young people fulfilling the recommended criteria for moderate physical activity, Poland ranks close to the average of 33 European countries, the U.S., and Canada [60]. Turnout at mass events has increased in recent years: the Poznań Half Marathon (by $800 \%$ since 2008), Poznań Triathlon (by 300\% since 2013), Poznań Bike Challenge (by $40 \%$ since 2014), and the Poznań Marathon (by 900\% since 2000) [61]. In contrast to running events, far less research addresses the motivation driving participation in mass, popular cycling events designed for amateurs, often in a family atmosphere, which, nonetheless, require a certain amount of psychophysical training.

\section{Research Aim}

The research aim was twofold: to investigate motives of participation in an amateur cycling race and evaluate the motivational differences between men and women. The case study was the fifth edition of the Skoda Bike Challenge. Understanding mass cycling motivations is of importance, as such knowledge can be used to encourage cycling, which has potentially positive effects on future cyclists' physical and mental health. Learning about cycling motivations also allows us to determine which functions of physical and mental health are fulfilled by mass sporting events and how to prepare for them. Our survey divided motives according to the MPAM-R (Motives for Physical Activity Measure-Revised). The MPAM-R addresses people's motives for doing sport. The following motives are evaluated; enjoyment, fitness, competence, social, and appearance. (1) Fitness refers to being physically healthy/active, energetic, and strong; (2) appearance refers to becoming physically more attractive, looking better, and reaching or keeping a desired weight; (3) challenge/competence refers to being physically active because of the need to improve at an activity, acquiring new skills, and facing a challenge; (4) social refers to being with friends and meeting new people during a sporting activity; (5) enjoyment refers to being physically active simply because it is interesting, fun, enjoyable, and makes you happy. The MPAM-R is a revised version of an earlier scale going by the same name. The previous measure by Frederick and Ryan [62] was shorter (including three motivations). The longer version was later validated and presented by Ryan, Frederick, Lepes, Rubio, and Sheldon [63]. The MPAM-R enables motives to be compared between different sports as opposed to research tools designed for the specificity of a single given discipline in sport (e.g., Motivation of Marathoners Scale (MOMS) research tool for runners).

\section{Materials and Methods}

\subsection{The Skoda Bike Challenge}

While the biggest cycling race for professional cyclists in Poland is the Tour de Pologne (used by the Polish Tourist Board to improve Poland's image abroad), the Skoda Bike Challenge (SBC) is the biggest mass cycling event for amateur cyclists in Poland. The event forms part of the UCI Gran Fondo World Series of events organized around the world, which are sanctioned by the Union Cycliste Internationale (UCI). The event is called the Tour de France for amateurs. In 2018, 4500 amateur cyclists took part in the two-day SBC event in Poznań. The event took place in the center of Poznan, one of the largest cities in Poland. The city is seeking to gain visibility through sport and tourism. Cyclists competed over distances of 120 and $50 \mathrm{~km}$. The organizers also prepared a special course for families with children - the Skoda Family Challenge. There was also a Kids Challenge where children aged 4-6 were able to participate. The SBC is a unique event in Poland, and Poznań is among the elite of just 15 organizers. Other hosts include Dubai and St. Tropez. Amateurs' motives for participating in mass cycling events have so far been rarely studied by researchers, especially in Europe. 


\subsection{Skoda Bike Challenge Participants}

A sample of 385 cyclist-respondents $(n=385) ; 290$ men and 95 women participated in the study. The men were mainly between 31 and 40 years of age (43\%) and the women mainly between 19 and 30 years (33.5\%). Further information on the cyclists is shown in Table 1.

Table 1. Information on cyclists (participants in the fifth edition of the Skoda Bike Challenge in Poznań).

\begin{tabular}{ccc}
\hline \multirow{2}{*}{ How Many Times Have You Taken Part in the Bike } & \multicolumn{2}{c}{ Percentage } \\
Challenge in Poznań? & Women: & Men: \\
& N =95 & N = 290 \\
\hline First & $28 \%$ & $28 \%$ \\
Second & $25 \%$ & $22 \%$ \\
Third & $25 \%$ & $26 \%$ \\
Fourth & $11 \%$ & $12 \%$ \\
Fifth & $11 \%$ & $12 \%$ \\
\hline Do you intend to take part in the Bike Challenge again in the future? \\
\hline Yes & $86.5 \%$ & $86.5 \%$ \\
No & $8 \%$ & $11 \%$ \\
I don't know & $5.5 \%$ & $2.5 \%$ \\
\hline Age & \multicolumn{2}{c}{} \\
\hline 18 or under & $9.5 \%$ & $3 \%$ \\
$19-30$ & $33.5 \%$ & $25 \%$ \\
$31-40$ & $32.5 \%$ & $43 \%$ \\
$41-50$ & $16 \%$ & $19 \%$ \\
51 and over & $8.5 \%$ & $10 \%$ \\
\hline
\end{tabular}

Source: the authors.

\subsection{Research Method and Procedure}

A diagnostic survey method with a standardized interviewing technique was used (research tool—an interview questionnaire). The respondents were interviewed (face-to-face) by the authors during the cycling event. We sought to select the sample in such a way as to ensure the best possible representation of the results obtained. Simple random sampling without replacement was used. In order to determine the number, evidence from the event organizers on the expected number of cyclists was used. The organizer's written consent for the study was obtained. Sample size formula for a finite population was used in the calculations. The assumption was made that the maximum error of the estimate (e), at a $95 \%$ confidence level, should not exceed $4 \%$.

\subsection{Data Analysis}

Descriptive statistics were applied. For the differences between responses, a chi-square test for independence was calculated. In the case of small expected numbers, the Yates' correction was used. The significance level $\alpha=0.05$ was assumed. Statistical significance was set at $p<0.05$. "Cramer's Phi $\varphi^{\prime \prime}$ (effect size for the chi-square test) was checked in the event of statistically significant results. All statistical analyses were conducted using Statistica Software 10.0 (StatSoft Inc., Cracow, Poland, 2011).

\section{Test Results}

The results obtained in this research try to describe the motives of participation of amateur athletes in mass cycling events, and to show the differences between sexes. Motivational readiness is fundamental in understanding motives of participation in mass sports events, and to promote and foster these sports competitions. 
Table 2 shows the social motives to participate by gender. There were no significant differences between sexes in any of the items $(p>0.05)$.

Table 2. Social motives.

\begin{tabular}{cccccc}
\hline Social & \multicolumn{2}{c}{$\begin{array}{c}\text { Percentage } \\
\text { Women: }\end{array}$} & Men: & $\chi^{2}$ & $\begin{array}{c}\boldsymbol{\varphi} \\
\text { Effect } \\
\text { Size }\end{array}$ \\
\hline $\begin{array}{c}\text { I like to be with others who are interested in this } \\
\text { sporting activity }\end{array}$ & $35.79 \%$ & $45.17 \%$ & 2.57 & 0.1087 & - \\
I want to be with my friends & $29.47 \%$ & $34.14 \%$ & 0.70 & 0.4014 & - \\
$\quad$ I want to meet new people & $10.53 \%$ & $9.66 \%$ & 0.60 & 0.8049 & - \\
My friends want me to take part & $25.26 \%$ & $18.97 \%$ & 1.74 & 0.1871 & - \\
$\quad \begin{array}{c}\text { I enjoy spending time doing this sporting activity } \\
\text { with other people }\end{array}$ & $37.89 \%$ & $40.69 \%$ & 0.23 & 0.6294 & - \\
\hline
\end{tabular}

Source: the authors.

Table 3 shows interest and enjoyment motives of athletes in the mass cycling event. There were significant differences in favor of the female sex $(p<0.001)$ when it comes to happiness "It makes me happy" (49.47\% women, $29.66 \%$ men). Regarding the rest of the enjoyment motives, there was no significant differences by sexes $(p>0.05)$.

Table 3. Interest/enjoyment motives.

\begin{tabular}{cccccc}
\hline \multirow{2}{*}{ Interest/Enjoyment } & \multicolumn{2}{c}{ Percentage } & \multirow{2}{*}{$\chi^{2}$} & p & $\boldsymbol{\varphi}$ \\
& Women: & Men: & & & \\
\hline I like the excitement of participating & $23.16 \%$ & $33.45 \%$ & 3.55 & 0.0596 & - \\
It's fun & $63.16 \%$ & $57.24 \%$ & 1.03 & 0.3094 & - \\
I like doing this activity & $43.16 \%$ & $54.48 \%$ & 3.68 & 0.0552 & - \\
It makes me happy & $49.47 \%$ & $29.66 \%$ & 12.43 & 0.0004 & 0.18 \\
I find this activity stimulating & $8.42 \%$ & $9.31 \%$ & 0.07 & 0.7936 & - \\
I think it's interesting & $26.32 \%$ & $22.76 \%$ & 0.50 & 0.4788 & - \\
I enjoy this activity & $25.26 \%$ & $28.62 \%$ & 0.40 & 0.5261 & - \\
\hline
\end{tabular}

Source: the authors

Table 4 shows statistical differences by gender in challenge and competence motives in favor of sportswomen $(p<0.05)$ "I want to get better at my activity" ( $23.16 \%$ women, $35.86 \%$ men). No statistical differences were found in the rest of challenge motives $(p>0.05)$.

Table 4. Competence/challenge motives.

\begin{tabular}{cccccc}
\hline Competence/Challenge & \multicolumn{2}{c}{ Percentage } & \multirow{2}{*}{$\chi^{2}$} & p & \multirow{2}{*}{$\boldsymbol{\varphi}$} \\
& Women: & Men: & & & \\
\hline I like engaging in physically challenging activities & $66.32 \%$ & $74.14 \%$ & 2.18 & 0.1397 & - \\
I want to acquire new skills & $17.89 \%$ & $11.72 \%$ & 2.36 & 0.1236 & - \\
I want to improve my existing skills & $18.95 \%$ & $27.24 \%$ & 2.61 & 0.1061 & - \\
I like the challenge & $47.37 \%$ & $51.38 \%$ & 0.46 & 0.4974 & - \\
I want to maintain my current level of skill & $18.95 \%$ & $27.24 \%$ & 2.61 & 0.1061 & - \\
I like activities which are physically challenging & $66.32 \%$ & $74.14 \%$ & 2.18 & 0.1397 & - \\
I want to get better at my activity & $23.16 \%$ & $35.86 \%$ & 5.25 & 0.0220 & 0.12 \\
\hline
\end{tabular}

Source: the authors.

Table 5 shows statistical differences in fitness motives in two of the items: "I want to be physically active" ( $57.89 \%$ women, $81.72 \%$ men) in favor of sportsmen $(p<0.001)$. "I want to maintain my physical strength to live a healthy lifestyle" (33.68\% women, $23.10 \%$ men) shows statistical differences with higher values for sportswomen $(p<0.05)$. However, no statistical differences were found in the rest of fitness motives $(p>0.05)$. 
Table 5. Fitness motives.

\begin{tabular}{|c|c|c|c|c|c|}
\hline \multirow{2}{*}{ Fitness } & \multicolumn{2}{|c|}{ Percentage } & \multirow{2}{*}{$x^{2}$} & \multirow[b]{2}{*}{$\mathbf{p}$} & \multirow{2}{*}{$\varphi$} \\
\hline & Women: & Men: & & & \\
\hline I want to be physically fit & $57.89 \%$ & $81.72 \%$ & 22.18 & 0.0000 & 0.24 \\
\hline I want to have more energy & $21.05 \%$ & $18.28 \%$ & 0.36 & 0.5490 & - \\
\hline I want to maintain my well-being and physical health & $49.47 \%$ & $51.38 \%$ & 0.10 & 0.7471 & - \\
\hline I want to improve my cardiovascular fitness & $21.05 \%$ & $25.17 \%$ & 0.66 & 0.4155 & - \\
\hline $\begin{array}{l}\text { I want to maintain my physical strength in order to live } \\
\text { a healthy lifestyle }\end{array}$ & $33.68 \%$ & $23.10 \%$ & 4.19 & 0.0406 & 0.10 \\
\hline
\end{tabular}

Source: the authors.

Table 6 shows that no significant differences were found between sexes in appearance motives of participation $(p<0.05)$

Table 6. Appearance motives.

\begin{tabular}{|c|c|c|c|c|c|}
\hline \multirow{2}{*}{ Appearance } & \multicolumn{2}{|c|}{ Percentage } & \multirow{2}{*}{$x^{2}$} & \multirow[b]{2}{*}{$\mathrm{p}$} & \multirow[b]{2}{*}{$\varphi$} \\
\hline & Women: & Men: & & & \\
\hline I want to maintain my weight so I look better & $21.05 \%$ & $25.17 \%$ & 0.66 & 0.4155 & - \\
\hline I want to look attractive to others & $3.16 \%$ & $5.52 \%$ & 0.85 & 0.3568 & - \\
\hline I want to improve my appearance & $13.68 \%$ & $10.34 \%$ & 0.80 & 0.3698 & - \\
\hline I feel physically unattractive if I don't & $7.37 \%$ & $4.14 \%$ & 1.59 & 0.2071 & - \\
\hline I want to improve my body shape & $11.58 \%$ & $9.31 \%$ & 0.41 & 0.5200 & - \\
\hline I want to define my muscles so that I look better & $10.53 \%$ & $10.00 \%$ & 0.20 & 0.8827 & - \\
\hline
\end{tabular}

Source: the authors.

Among women, the most frequently reported motives for actively participating in the Bike Challenge sport event were: "I like activities which are physically challenging" $-66.32 \%$, as shown in Table 4, "It's fun" - 63.16\%, "I want to be physically fit" - 57.89\%, as shown in Table 5, "It makes me happy" $-49.47 \%$, as shown in Table 3. Among men, the most frequently reported motives were: "I want to be physically fit" $-81.72 \%$, as shown in Table 5, "I like physically challenging activities" $-74.14 \%$, as shown in Table 4, "It's fun"- $57.24 \%$, "I like doing this activity" $-54.48 \%$, as shown in Table 3, "I want to maintain my physical health and well-being"-51.38\%, as shown in Table 5,"I like the challenge" $-51.38 \%$, as shown in Table 4 .

\section{Discussion}

The aim of our study was twofold: to investigate the motives for participating in an amateur cycling race and to evaluate the motivational differences between men and women. The results showed that sportsmen are more motivated to participate in mass sports events related to performance and to be physically fit. Instead, sportswomen's motivation to participate is more orientated to health and happiness.

Contemporary mass sporting events are an important element of tourist destination marketing strategies. They are used to shape a region's image. However, the motives driving amateur cyclists to participate in mass sporting events constitute a research niche because studies normally address professional and qualified cyclists [64]. Snelgrove and Wood analyzed the factors influencing participation in a charity sporting event among cyclists visiting a place for the first time and on subsequent occasions. Tourists visiting for the first time were more motivated by the opportunity to explore the destination whereas the other type of visitors were more motivated by sports-related identities [65]. Coghlan also analyzed the specifics of charity cycling events as an alternative form of sporting event tourism [66]. Rauter and Topic compared mountain biker and road cyclist motivations. They reported that mountain bikers have slightly different values, which are usually typical of extreme athletes. Mountain bikers more often feel the need to take risks and seek new experiences [67]. 
This research replicates findings obtained in other social contexts, e.g., LaChausse analyzed the differences in motivations between men and women in the U.S. using a modified version of the MOMS (Motivation of Marathoners Scale). In the line with our research, it transpired that male cyclists were more motivated by the need for competitive sport than female cyclists, and women pointed more to issues related to personal health and wellbeing, such as weight, the need for social belonging (affiliation), and self-esteem [68]. Our study results show that social motives connected with affiliation have similar significance to both male and female cyclists. The motive "I feel physically unattractive if I don't" connected with self-esteem and has similar significance to both male and female cyclists. Also, the motive "I want to maintain my weight so that I look better" has similar significance to both male and female cyclists. Our results do not therefore converge.

Heesch et al. studied motivational differences, according to gender and the restrictions associated with cycling in Australia, separately for cycling transportation and recreation. Respondents assessed the importance of 18 aspects that motivate them to cycle. Both male and female cyclists reported individual causes (health or pleasure), but female cyclists responded more that they were also motivated by other individual, environmental, and social causes. The most important factors in relation to cycling for most representatives of both genders were individual causes related to health (improving or maintaining their physical condition, relieving tension, relaxation, improving physical fitness, leading to an intensive lifestyle) and pleasure (outdoor fun). Women, however, reported their significance more than men. Women reported other personal motivators more than men (belief in their own abilities and skills), social factors (sharing an activity with other people who have a similar passion, participating in sporting events), and environmental factors (inexpensive means of transport, caring for the environment) are also important [69]. In our study, the factors related to health and enjoyment were also highly ranked, but one of the highest ranking motives was also the motive involving challenge. According to the results obtained by McCormick et al., the main reasons for taking part in sporting events such as running, cycling, and triathlons were taking them as a challenge [15]. Our results show that social needs are of similar importance to both women and men.

Ogles et al. analyzed motivations for running among male and female runners. Results showed that one the most common motives for running among women, the researchers mention, is social needs and concern for their appearance and physical fitness, while men are more likely to compete and be successful [17]. The motive in our study "I want to be physically fit" was more important for men, and social needs are of similar importance to both women and men.

Malchrowicz-Mośko and Poczta analyzed the differences between male and female motivations for participating in a half marathon. The difference between male and female runners transpired in the desire to get away from everyday life, which has greater significance to female than male runners [19]. This study reveals a similar situation-women participate more in the Bike Challenge event because it makes them happy.

\section{Final Conclusions}

Our findings show some differences between the male and female motives behind cycling. Women more often participate in the Bike Challenge events because it gives them happiness and because they want to lead an active and healthy lifestyle. On the other hand, the main motives for men to participate in these events are to be physically active or fit and the desire to be better in cycling. This is important data from the point of view of promoting cycling, and for organizers of cycling events in areas wishing to develop sports tourism as a form of sustainable development, especially since organizing cycling events does not require very expensive infrastructure. Further understanding of mass cycling motivations is needed, as such knowledge can be used to encourage cycling, which has potentially positive effects on future cyclists' physical and mental health. Such knowledge is also important in order to promote female sport because women are usually not as active as men, and more sports tourists are male [19,70-72]. Learning about cycling motivations also enables us to determine 
which physical and mental health functions are fulfilled by mass sporting events and how to prepare for them.

The cross-sectional design of the research was a limitation, since it did not allow causal inferences between the studied variables. In the future, collecting the data in two different moments would help to improve the knowledge about athletes' motives of participation in mass sports events [73]. Also, it would be worth examining the motivations for participating in mass sporting events in other sports, as this would allow comparative analyses to be carried out in the future. Cycling motivations depending on age should also be checked. Motivational characteristics of non-participants in mass sports events would provide relevant information that should be taken into account when developing intervention programs

In conclusion, a main implication for practice in these mass events arose from this research: The need to promote programs depending on the motivational orientation of sportsmen and sportswomen. These programs could focus on how to inspire women to participate in mass cycling events. For instance, the following measures could be taken into account to increase the number of women included in the data collection or even asking women about the barriers that may hinder their participation. Also, avoiding comparisons between women could lead to an increase in their participation. At the same time, sport marketing should consider these measures to ensure they appeal across genders, promoting at the same time popular women athletes' images, beyond high performance athletes. Thereby, the organization and design of social campaigns and marketing strategies plays a twofold role as they can empower both gender athletes, and they also can have psychological, physical, and behavioral benefits on these athletes. In addition, the participation in cycling events can lead to cycle use as transport on a daily basis, resulting in regular training and exercising for future sport events.

Thus, our results indicate the existence of significant motivational differences among female and male athletes' practice; thereby, promotion and adherence [74] programs need to take such differences into consideration.

Author Contributions: Conceptualization, E.M.-M.; methodology, E.M.-M.; software, E.M.-M., K.A., P.L.-G.; validation, E.M.-M.; formal analysis, E.M.-M.; investigation, M.M.; resources, E.M.-M., K.A., P.L.-G.; data curation, E.M.-M.; writing-original draft preparation, E.M.-M.; writing—review and editing, E.M.-M., K.A., P.L.-G.; visualization, E.M.-M.; supervision, E.M.-M.; project administration, E.M.-M.

Funding: This research received no external funding.

Conflicts of Interest: The authors declare no conflict of interest.

\section{References}

1. Girginov, V.; Hills, L. A sustainable sports legacy: Creating a link between the London Olympics and sports participation. Int. J. Hist. Sport 2008, 25, 2091-2116. [CrossRef]

2. Taks, M.; Misener, L.; Green, C. Evaluating sport development outcomes: The case of a medium-sized international sport event. Eur. Sport Manag. Q. 2014, 14, 213-237. [CrossRef]

3. Hylton, K.; Bramham, P. Sport Development: Policy, Processes and Practice; Routledge: Abingdon, UK, 2008.

4. Poczta, J.; Malchrowicz-Mośko, E. Modern Running Events in Sustainable Development-More than Just Taking Care of Health and Physical Condition (Poznan Half Marathon Case Study). Sustainability 2018, 10, 2145. [CrossRef]

5. Lopez-Bonilla, J.M.; Reyes-Rodriguez, M.; Lopez-Bonilla, L.M. The Environmental Attitudes and Behaviours of European Golf Tourists. Sustainability 2018, 10, 2214. [CrossRef]

6. O'Connor, J.P.; Brown, T.D. Real cyclists' don't race: Informal affiliations of the weekend warrior. Int. Rev. Sociol. Sport 2007, 42, 83. [CrossRef]

7. Garrard, J.; Rose, G.; Lo, S.K. Promoting transportation cycling for women: The role of bicycle infrastructure. Prev. Med. 2007, 46, 55-59. [CrossRef] [PubMed]

8. Sallis, J.F.; Owen, N. Ecological models of health behavior. In Health Behavior and Health Education-Theory, Research and Practice; Glanz, K., Rimer, B., Lewis, F., Eds.; Jossey-Bass: San Francisco, CA, USA, 2002. 
9. Oja, P.; Titze, S.; Bauman, A.; de Geus, B.; Krenn, P.; Reger-Nash, B.; Kohlberger, T. Health benefits of cycling: A systematic review. Scand. J. Med. Sci. Sports 2011, 21, 496-509. [CrossRef]

10. Andersen, L.B.; Schnohr, P.; Schroll, M.; Hein, H.O. All-cause mortality associated with physical activity during leisure time, work, sports, and cycling to work. Arch. Intern. Med. 2000, 160, 1621-1628. [CrossRef]

11. Deci, E.L.; Ryan, R.M. Intrinsic Motivation and Self-Determination in Human Behavior; Plenum: New York, NY, USA, 1985.

12. Hulleman, M.; de Koning, J.J.; Hettinga, F.J.; Foster, C. The Effect of Extrinsic Motivation on Cycle Time Trial Performance. Available online: www.s3.amazonaws.com/academia.edu.documents/44928839/ (accessed on 1 September 2019).

13. Frederick-Recascino, C.M.; Schuster-Smith, H. Competition and intrinsic motivation in physical activity: A comparison of two groups. J. Sport Behav. 2003, 26, 240.

14. Streitcher, H.; Saayman, M. Travel motives of participants in the Caper Argus Pick n Pay Cycle Tour. S. Afr. J. Res. Sport Phys. Educ. Recreat. 2010, 32, 121-131.

15. McCormick, A.; Anstiss, P.A.; Lavallee, D. Endurance athletes' current and preferred ways of getting psychological guidance. Int. J. Sport Exerc. Psychol. 2018. Available online: www.tandfonline.com/doi/full/ 10.1080/1612197X.2018.1486874 (accessed on 1 September 2019). [CrossRef]

16. Krouse, R.; Ransdell, L.; Lucas, S.; Pritchard, M. Motivation, goal orientation, coaching and training habits of women ultrarunners. J. Strength Cond. Res. 2011, 25, 2835-2842. [CrossRef] [PubMed]

17. Ogles, B.M.; Masters, K.S. Obligatory running and gender: An analysis of participative motives and training habits. Int. J. Sport Psychol. 1995, 26, 233-248.

18. Summers, J.J.; Machine, V.J.; Sargent, G.I. Psychosocial factors related to marathon running. J. Sport Psychol. 1983, 5, 314-331. [CrossRef]

19. Malchrowicz-Mośko, E.; Poczta, J. Running as a Form of Therapy. Socio-Psychological Functions of Mass Running Events for Men and Women. Int. J. Environ. Res. Public Health 2018, 15, 2262. [CrossRef] [PubMed]

20. Frick, B. Gender Differences in Competitive Orientations: Empirical Evidence from Ultramarathon Running. J. Sport Econ. 2011, 12, 317-340. [CrossRef]

21. Smith, A. A Qualitative Analysis of Motivation of Elite Female Triathletes. Available online: https:// scholarworks.sjsu.edu/cgi/viewcontent.cgi?article=4826\&=\&context=etd_theses \&=\&sei-redir=1\&referer= https\%253A\%252F\%252Fscholar.google.pl\%252Fscholar\%253Fstart\%253D10\%2526q\%253Dtriathlon\% 252Bmotivation\%2526hl\%253Dpl\%2526as_sdt \%253D0\%252C5\#search=\%22triathlon \%20motivation \%22 (accessed on 16 October 2019).

22. Fernandez-Lopez, I.; Merino-Marban, R.; Fernandez-Rodriguez, E. Examining the Relationship between Sex and Motivation in Triathletes. Percept. Motor Ski. 2014, 119, 42-49. [CrossRef]

23. Amiri, M.; Sadeghpour, F. Cycling characteristics in cities with cold weather. Sustain. Cities Soc. 2015, 14, 397-403. [CrossRef]

24. Woodcock, J.; Banister, D.; Edwards, P.; Prentice, A.M.; Roberts, I. Energy and health—energy and transport. Lancet 2007, 370, 1078-1088. [CrossRef]

25. Damant-Sirois, G.; Grimsrud, M.; El-Geneidy, A.M. What's your type: A multidimensional cyclist typology. Transportation 2014, 41, 1153-1169. [CrossRef]

26. Johnson, M.; Rose, G. Extending life on the bike: Electric bike use by older Australians. J. Transp. Health 2015, 2, 276-283. [CrossRef]

27. Oja, P.; Vuori, I.; Paronen, O. Daily walking and cycling to work: Their utility as health-enhancing physical activity. Patient Educ. Couns. 1998, 33, s87-s94. [CrossRef]

28. Damant-Sirois, G.; El-Geneidy, A.M. Who cycles more? Determining cycling frequency through a segmentation approach in Montreal, Canada. Transp. Res. Part A: Policy Pract. 2015, 77, 113-125. [CrossRef]

29. Lumsdon, L. Transport and Tourism: Cycle Tourism-A Model for Sustainable Development? J. Sustain. Tour. 2000, 8, 361-377. [CrossRef]

30. Han, H.; Meng, B.; Kim, W. Emerging bicycle tourism and the theory of planned behavior. J. Sustain. Tour. 2017, 25, 292-309. [CrossRef]

31. Shipway, R.; Jones, I. Running away from home: Understanding visitor experiences and behaviour at sport tourism events. Int. J. Travel Res. 2007, 78, 641. [CrossRef] 
32. Nowak, P.; Chalimoniuk-Nowak, M. Running tourism in Poland. Example of tourist activity of Polish marathon runners. Br. J. Educ. Soc. Behav. Sci. 2015, 5, 416-425. [CrossRef]

33. Nikolaidis, P.T.; Chalabaev, A.; Rosemann, T.; Knechtle, B. Motivation in the Athens Classic Marathon: The Role of Sex, Age, and Performance Level in Greek Recreational Marathon Runners. Int. J. Environ. Res. Public Health 2019, 16, 2549. [CrossRef]

34. Nikolaidis, P.T.; Alvero-Cruz, J.R.; Villiger, E.; Rosemann, T.; Knechtle, B. The Age-Related Performance Decline in Marathon Running: The Paradigm of the Berlin Marathon. Int. J. Environ. Res. Public Health 2019, 16, 2022. [CrossRef]

35. Malchrowicz-Mośko, E.; Płoszaj, K.; Firek, W. Citius, Altius, Fortius vs. Slow Sport: A New Era of Sustainable Sport, Special Issue: Effect of Sport Activity on Health Promotion. Int. J. Environ. Res. Public Health 2018, 15, 2414. [CrossRef]

36. Malchrowicz-Mośko, E.; Botikova, Z.; Poczta, J. Because We Don't Want to Run in Smog-Problems with the Sustainable Management of Sport Event Tourism in Protected Areas (A Case Study of National Parks in Poland and Slovakia), Special Issue: Sport and Sustainability. Sustainability 2019, 11, 325. [CrossRef]

37. Kolar, J. Exploring combined tourist offering: The case of sightrunning. Curr. Issues Tour. 2019, 22, 400-408. [CrossRef]

38. Smith, A. Reimaging the city: The value of sport initiatives. Ann. Tour. Res. 2005, 32, 217-236. [CrossRef]

39. Lamont, M. Reinventing the Wheel: A Definitional Discussion of Bicycle Tourism. J. Sport Tour. 2009, 14, 5-23. [CrossRef]

40. Flusche, D. Bicycling Means Business. The Economic Benefits of Bicycle Infrastructure. Available online: www.trid.trb.org/view/1225592 (accessed on 9 September 2019).

41. Ritchie, B.W.; Tkaczynski, A.; Faulks, P. Understanding the Motivation and Travel Behavior of Cycle Tourists Using Involvement Profiles. J. Travel Tour. Mark. 2010, 27, 409-425. [CrossRef]

42. Lee, C.F.; Huang, H.I. The Attractiveness of Taiwan as a Bicycle Tourism Destination: A Supply-Side Approach. Asia Pac. J. Tour. Res. 2014, 19, 273-299. [CrossRef]

43. Buning, R.J.; Gibson, H.J. The role of travel conditions in cycling tourism: Implications for destination and event management. J. Sport Tour. 2016, 20, 175-193. [CrossRef]

44. Willis, D.P.; Manaugh, K.; El-Geneidy, A.M. Uniquely satisfied: Exploring cyclist satisfaction. Transp. Res. Part F: Traffic Psychol. Behav. 2013, 18, 136-147. [CrossRef]

45. Brown, T.D.; O'Connor, J.P.; Barkatsas, A.N. Instrumentation and Motivations for Organised Cycling: The Development of the Cyclist Motivation Instrument (CMI). J. Sports Sci. Med. 2009, 8, 409-425.

46. Malchrowicz-Mośko, E.; Chlebosz, K. Sport Spectator Consumption and Sustainable Management of Sport Event Tourism. Fan Motivation in High Performance Sport and Non-Elite Sport. A Case Study of Horseback Riding and Running-A Comparative Analysis. Special Issue: Tourism, Governance and Sustainable Development. Sustainability 2019, 11, 2178. [CrossRef]

47. Malchrowicz-Mośko, E.; Poczta, J. A Small-Scale Event and a Big Impact-Is This Relationship Possible in The World of Sport? The Meaning of Heritage Sporting Events for Sustainable Development of Tourism-Experiences from Poland. Sustainability 2018, 10, 4289. [CrossRef]

48. Chappelet, J.L. Heritage Sporting Events and Place Marketing. 2015. Available online: www.core.ac.uk/ download/pdf/77151599.pdf (accessed on 1 November 2019).

49. Banio, A.; Malchrowicz-Mośko, E.; Rozmiarek, M.; Omorczyk, A. Dziedzictwo igrzysk olimpijskich a polityka Międzynarodowego Komitetu Olimpijskiego. Rozpr. Nauk. AWF We Wrocławiu 2018, 63, 11-27.

50. Margaritis, G.; Rozmiarek, M.; Malchrowicz-Mośko, E. Tangible and Intangible Legacy of the 19th Century Zappas Olympics and their Implications for Contemporary Sport Tourism. Phys. Cult. Sport Stud. Res. 2017, 74, 57-60. [CrossRef]

51. Available online: www.turystykawmiescie.org/2016/02/20/turystyka-rowerowa-narodowy-produktturystyczny-polski-relacja/ (accessed on 5 August 2019).

52. Available online: www.eko.org.pl/seminarium/2.html (accessed on 6 August 2019).

53. Biernat, E.; Piatkowska, M. Recreational Phycial Activity of Poles in the Light of Europe-Report; Ministry of Sport and Tourism: Warsaw, Poland, 2012.

54. Physical Activity of Poles TNS-Report; Ministry of Sport and Tourism: Warsaw, Poland, 2015. 
55. Lenartowicz, M.; Dziubinski, Z.; Jankowski, K. Aktywni Polacy: Dwie dekady uczestnictwa w sporcie i rekreacji ruchowej. Próby wyjaśnienia zmian (Active Poles: Two decades of participation in sport and recreation. Attempts to explain changes). Kult. i Społeczeństwo (Cult. Soc.) 2017, 2, 195-210.

56. Domanski, H. Polska Klasa Średnia (Polish Middle Class); Wroclaw University: Wroclaw, Poland, 2000.

57. Sport Development Programme 2020; Polish Ministry of Sport and Tourism: Warsaw, Poland, 2015.

58. Sport and Physical Activity; Special Eurobarometer: Brussels, Belgium, 2014.

59. Participation of Poles in Sport and Active Recreation; Central Statistical Office: Warsaw, Poland, 2013.

60. Social Determinants of Health and Well-Being among Young People-International Report; WHO Regional Office for Europe: Copenhagen, Denmark, 2012.

61. Malchrowicz-Mośko, E.; Młodzik, M.; Banio, A.; Omorczyk, A. Triathlon as a Form of Sports Consumption. Motives for Participation. Tourism 2018, 28, 41-48. [CrossRef]

62. Frederick, C.M.; Ryan, R.M. Differences in motivation for sport and exercise and their relationships with participation and mental health. J. Sport Behav. 1993, 16, 125-145.

63. Ryan, R.M.; Frederick, C.M.; Lepes, D.; Rubio, N.; Sheldon, K.M. Intrinsic motivation and exercise adherence. Int. J. Sport Psychol. 1997, 28, 335-354.

64. Wiesner, W.; Smolarski, T.; Szwej, P. Characteristics of Cyclists Practicing Cycling in the Jizera Mountains. In Rozprawy Naukowe Akademii Wychowania Fizycznego we Wrocławiu; Akademia Wychowania Fizycznego: Wrocławiu, Poland, 2016; p. 55.

65. Snelgrove, R.; Wood, L. Attracting and Leveraging Visitors at a Charity Cycling Event. J. Sport Tour. 2010, 15, 269-289. [CrossRef]

66. Coghlan, A. An autoethnographic account of a cycling charity challenge event: Exploring manifest and latent aspects of the experience. J. Sport Tour. 2017, 12, 105-124. [CrossRef]

67. Rauter, S.; Topic, M.D. Sport activity and sport motives of mountain bikers and road cyclists. Ido Mov. Cult. 2010, 10, 36-40.

68. LaChausse, R. Motives of Competitive and Non-Competitive Cyclists. J. Sport Behav. 2006, 29, 304-314. Available online: search.proquest.com/openview/cc6bd9580bbbd227931d90f3966d5338/1?pqorigsite $=$ gscholar\&cbl $=30153$ (accessed on 10 September 2019).

69. Heesch, K.C.; Sahlqvist, S.; Garrard, J. Gender differences in recreational and transport cycling: A cross-sectional mixed-methods comparison of cycling patterns, motivators, and constraints. Int. J. Behav. Nutr. Phys. Act. 2012, 8, 106. [CrossRef] [PubMed]

70. Malchrowicz-Mośko, E.; Poczta, J.; Adamczewska, K. The Potential of Non-Mega Sporting Events for the Promotion of Physical Activity Among Inactive Supporters at the Poznan Half Marathon: A Case Study. Int. J. Environ. Res. Public Health 2019, 16, 4193. [CrossRef] [PubMed]

71. Ross, D. Developing Sports Tourism. National Laboratory for Tourism; University of Illinois: Champaign, IL, USA, 2001.

72. Stratas, A.; Karlis, G.; Locke, M.; Gravelle, F.; Arora, G. Serving the Health Care and Leisure Needs of Ethnic Aged in Canada: Implications and Concerns. Phys. Cult. Sport. Stud. Res. 2018, 80, 5-14.

73. Willem, A.; De Rycke, J.; Theeboom, M. The role of autonomous and controlled motivation in exercise intentions of participants in a mass cycling event. Front Psychol. 2017, 8, 354. [CrossRef]

74. Coleman, S.J.; Sebire, S.J. Do people's goals for mass participation sporting events matter? A self-determination theory perspective. J Public Health 2017, 39, 202-208.

(C) 2019 by the authors. Licensee MDPI, Basel, Switzerland. This article is an open access article distributed under the terms and conditions of the Creative Commons Attribution (CC BY) license (http://creativecommons.org/licenses/by/4.0/). 